Drevland, F.and Tillmann, P. A. (2018). "Value for whom?" In: Proc. 26 th Annual Conference of the International. Group for Lean Construction (IGLC), González, V.A. (ed.), Chennai, India, pp. 261-270. DOI: doi.org/10.24928/2018/0533. Available at: www.iglc.net.

\title{
VALUE FOR WHOM?
}

\author{
Frode Drevland ${ }^{1}$ and Patricia A. Tillmann²
}

\begin{abstract}
Designing, building and optimising projects as production systems producing value can be said to be the aim of construction management from an engineering perspective. However, the question is whose value are we optimising the system for? The lean philosophy tells we should deliver value to all the projects customers. However, here anyone that is impacted by the project is considered a customer, not just the paying client. Do all customers matter and is delivering value for all of them of equal importance?

In this paper, we explore this matter by first looking into the literature on stakeholder management. Finding no suitable answers there we attack the question by considering the motivations for delivering value by a literature review and interviews with industry professionals. Finally, we discuss the implications that considering the perspective of multiple stakeholders brings to project management.

The paper argues that the key to deciding whose value matter lies in understanding the motivation for why valueis delivered. However, to what degrees different factors motivates someone will be highly dependent on their philosophical outlook, thus making the matter of value for whom a philosophical question.
\end{abstract}

\section{THE CONCEPT OF VALUE}

\section{KEYWORDS}

Lean construction, value, theory, value philosophy, stakeholder management

\section{INTRODUCTION}

Engineering can be said to befocused on systems, how to design, build and optimise them. Within the lean construction community, projects are consideredproduction systems (Koskela and Ballard 2006) and that the goal of these production systems is to deliver value (Emmitt et al. 2005). Thus, we would argue the natural focus of construction management is to support the delivery of value from projects. However, there is acritical question that needsan answered in this context: if valueis subjective or particular

Assistant Professor, NTNU - Norwegian University of Science and Technology, Trondheim, Norway, +47 92064 262, frode.drevland@ntnu.no

2 Senior Lean Manager, University of California San Francisco, California, +14152799102, patricia.andretillmann@ucsf.edu 
(Bertelsen and Emmitt 2005; Drevl and and Lohne 2015; Holbrook 1998), then whose value are we considering when optimising the system?

The standard answer in lean is that we should deliver value to the customer. Here, however, customermay refer not only to the paying client but also to everyone who is in any way impacted by the project. In other words, the term customeris closely related to what the general project management literature refers to as a stakeholder. According to the Project Management Body of Knowledge, a stakeholder is "an individual, group, or organisation, who may affect, be affected by, or perceive itself to be affected by a decision, activity, or outcome of a project"(PMI 2013).

Construction projects produce massive land bound products. On these projects, many stakeholders are involved, including different local, state and federal government departments, non-governmental organizations, private companies, and the community. This intricate network of stakeholders often results in requirement conflicts and need to spend some effort managing trade-offs and the expectations of different groups of stakeholders involved (Tillmann et al. 2011). Even though past research has identified that stakeholders with conflicting requirements are a challenge to project management practices in construction, there is a lack of reflection (with theoretical support) on why these challenges exist and what is the implications for value generation. Whose value matter?Is value for all stakeholders of equal importance? If we want to deliver value through our projects, then answering these questions is a fundamental step.

Whose value matters have been discussed by several authors in the IGLC community(Bertelsen and Emmitt 2005; Drevland and Svalestuen 2013; Pasquire and Salvatierra-Garrido 2011; Salvatierra-Garrido and Pasquire 2011), however, there exists no collective agreement regarding the issue of whose value matter, or even if value for different stakeholders should have the same weight.This paper explores stakeholder theory and motivations for delivering value and present the argument that there is no one prescriptive solution to the matter to be found, as the question of value for whom is at its core matter of philosophy.

\section{THE CONCEPT OF VALUE}

Before we address the question of value for whom, we find it necessary to first define value as a term. Value is an ill-definedconcept without any commonly agreed upon definition(Drevland and Lohne 2015; Salvatierra-Garrido et al. 2012; Thyssen et al. 2010). The most common definition of value in the construction project literature is that value the relationship between what yougive and what youget(Kelly et al. 2004). However, many conflate the termvalue with benefits (Drevland and Lohne 2015; Laursen and Svejvig 2016). In this paper, our understanding of value is by Drevland and Lohne (2015). They give a comprehensive, but rather a lengthy definition of value, however, the essence of it is that value is the result of an evaluative judgment of what someone get and what they give. The value will be different for each stakeholder based on their judgment of the get and give factors that matter to them. 


\section{METHOD}

We have done this research on founded on the pragmatic research paradigm, where truth is notsomething that is entirely objective, like in positivism, or entirely subjective, like in constructivism, but rather a matter of useful belief (Rorty 1999).

Our first step was to do a scoping study, as described by Arksey and O’Malley (2005), to identify relevant literature in the field of stakeholder management. When it became evident that the literature here could not adequately answer questions at hand, we started looking at motivations for why actors deliver value and expanded the scoping study accordingly.

In addition to the scoping study, we supplemented with data from two-case studied that was carried out in research done by the authors parallel to this research. Both cases were hospital projects. One Lean-IPD project located in San-Francisco and one more traditional design-build located in Troms $\varnothing$, Norway. Data gathering was done using semistructured interviews according to Robson (2002). We interviewed a total of 14 practitioners serving in different roles on the projects (owners, project managers, architects, engineers and contractors.

\section{STAKEHOLDER GROUPS}

Oke and Aigbavboa (2017) reviewed several different construction-related studies that identified stakeholders with direct and indirect links to project construction, and summarised that:

"Typical stakeholders in the construction industry include the following, among others: client, owner, sponsor, financier, principal contractor, trade contractor or subcontractor, material supplier, subcontractor, architect, quantity surveyor, employee, engineer, archaeologist, sustainability consultant, development manager, local government, national government, design coordinator, regulatory agency, managing director, technical director, conservationist, environmentalist, project manager, area manager, builder, construction manager, project manager, land surveyor, estate surveyor and other specialist consultants. Others are client's customers, client's employees, client's tenants, client's suppliers, local residents, and local landowners among others."

Although Oke and Aigbavboa (2017) provide a starting point to understand the stakeholders in a construction project, their classification does not make a distinction among the different levels of influence they might have on defining value. Furthermore, given the way construction projects are organised, such classification does not help us understand how to group these stakeholders. For example, an engineer could be an employee of a contractor, sub-contractor, specialist-consultant and manyothers on that list.

Rather than relying on existing classification of stakeholders, we have chosen to define stakeholder groupings as shown in Table 1.The basis for this has been which groups we have found useful to distinguish between to discuss the matter at hand. 
Table 1 Stakeholder groups

\begin{tabular}{ll}
\hline $\begin{array}{l}\text { Stakeholder } \\
\text { groups }\end{array}$ & Description \\
\hline Owner & $\begin{array}{l}\text { Person or company who initiates and finances the facility, and } \\
\text { takes ownership of it at the end to useit themselves, renting it out } \\
\text { or selling it. }\end{array}$ \\
\hline Tenants & $\begin{array}{l}\text { Person or company that rents the entire or parts of the facility } \\
\text { from the owner }\end{array}$ \\
\hline Users & $\begin{array}{l}\text { People who in some way interact directly with the building, i.e. } \\
\text { people who work in and visit the facility for any purpose }\end{array}$ \\
\hline Financial & $\begin{array}{l}\text { Organizations who have a vested interested in the facility by } \\
\text { financed or insured it }\end{array}$ \\
\hline Neighbours & Anyone directly affected by the facility in its surrounding areas \\
\hline Society at large & $\begin{array}{l}\text { The general public and society as a whole. Typically represented } \\
\text { by government institutions. }\end{array}$ \\
\hline Designers & $\begin{array}{l}\text { Architectural and engineering firms responsible for the design of } \\
\text { the facility }\end{array}$ \\
\hline Builders & $\begin{array}{l}\text { Contractors and others responsible for the building the physical } \\
\text { facility on site }\end{array}$ \\
\hline Suppliers & Anyone providing parts or materials \\
\hline
\end{tabular}

In Mitchell et al. (1997)'s seminal typology of stakeholders, there are three attributes which are used to classify stakeholders

- Power-Stakeholders ability to impose on the project

- Legitimacy- Legitimate relationship with the project

- Urgency - The degree to which stakeholder claims call for immediate attention

In the context of projects and value delivery, we posit that urgency is here a matter of receiving some value from the project, be it positive or negative. I.e. a stakeholder whose value is not impacted has no urgency. Furthermore, we posit that stakeholders with a legitimate relationship are those that have a formal relationship with the project, either contractual or regulatory.

The three binary categories combined yields seven different categories of stakeholder as shown in Figure 1. However, we would argue that in the context of value delivery, only the stakeholders whose value matter are of interest, i.e. stakeholders with urgency. Thus, the stakeholder categories with no urgency can be ignored, leaving us with:

- Demanding stakeholdershavean urgent claim but no power and legitimacy.

- Dependent stakeholders have the urgency and legitimacy but no power.

- Dangerous stakeholders lack legitimacy but possess power and urgency.

- Definitive stakeholders possess all of the three attributes. 


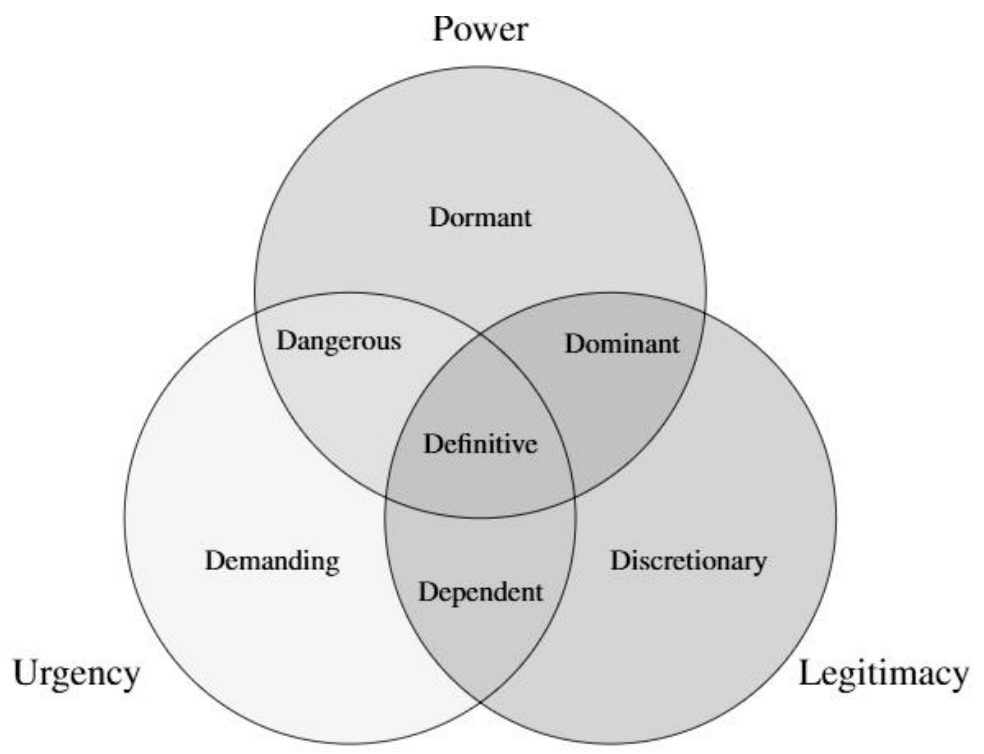

Figure 1: Stakeholder typology (based on Mitchell et al. 1997)

\section{MAPPING STAKEHOLDER GROUPS TO CLASSES}

Based on the previously presented stakeholder groups and Mitchell et al. (1997)'s stakeholder typology, we created a mapping between them as shown in Table 2.

Table 2 Stakeholder groups mapped to classes

\begin{tabular}{ccccc} 
Stakeholder group & Definitive & Dependent & Dangerous & Demanding \\
Owner & $\mathrm{X}$ & & \\
Tenants & & $\mathrm{X}$ & \\
Users & & $\mathrm{X}$ & \\
Financial institutions & & $\mathrm{X}$ & $\mathrm{X}$ \\
Neighbours & & $\mathrm{X}$ & $\mathrm{X}$ \\
Society at large & $\mathrm{X}$ & & \\
Designers & $\mathrm{X}$ & & \\
Builders & $\mathrm{X}$ & & \\
Suppliers & & $\mathrm{X}$ & \\
\hline
\end{tabular}

The owner is arguably the definitive stakeholder, being the one who usually would have the most legitimacy and urgency and wields the most power in the project. While tenants, users and financial institutions can all be said to have legitimacy and urgency, yet they cannot impose directly on the project, but instead are dependent on the owner's power.

Neighbours similarly do not have any power on their own, but instead are reliant on the government institutions of society at large. Their legitimacy will depend on what 
rights they have through laws and regulations, and thus will be either dependent or demanding.

Society atlargeis both a definitive and demanding stakeholder. It has significant legitimacy and wields considerable power in those areas society has decided should be governed by laws and regulations. However, society at large will have interests beyond what is strictly regulated and governed. Arguably, the rules and regulations put in place by societyare to prevent harm to be done to it, not to ensure that good is done. Furthermore, while this might hold true for well-regulated countries in the developed world, the situation in developing countries will be different. Therefore, to which degree society at large is a definitive or demanding stakeholder will vary significantly depending on the context of the project.

Designers and builders, having a contractual agreement will have legitimacy, urgency and power and should, therefore, be considered definitive stakeholders as groups.

Suppliers typically do not have a direct relationship with the project, but rather through the designers and builders and can thus be considered dependent stakeholders.

\section{ARE POWER AND LEGITIMACY ALL THAT MATTERS?}

We would argue that stakeholder theory, can be helpful in determining who might want to influence the projects, their ability to do so and their interests. It does, however, little in helping in deciding whose value we should care fore, beyond the need to appease those with power. For example, Mitchell et al. (1997) argue that Demanding stakeholders are pure noise that should be ignored until they acquire either power or legitimacy. However, we do not believe that this sentiment holds true in the construction industry. Architects and engineers tend to have a desire to serve the greater good, and not just the paying client. Therefore, rather than starting by considering who has the power to determine what value to deliver, we argue it is more fruitful to begin by looking at the motivation for why different actorsdelivervalue.

\section{WHAT MOTIVATES VALUE DELIVERY}

In this section, we reflect based on the findings from data collected through literature study and interviews. We identified different motivations for delivering value and mapped them in a taxonomy shown if Figure 2. Each category is further explained in the following subsections.

\section{TRANSACTIONAL MOTIVATION}

The primary motivation for value delivery will typically centre around the formal transaction. That is, two or more parties have a formal agreed-upon exchange of give and get. We define value that is delivered directly to satisfy some condition set forth herein as being related to the core of the transaction. Also, the parties to the formal agreement might have to delivervalue to third-partystakeholders to enable the transaction. For example, the city will only give out building permits if the design is according to building codes. 


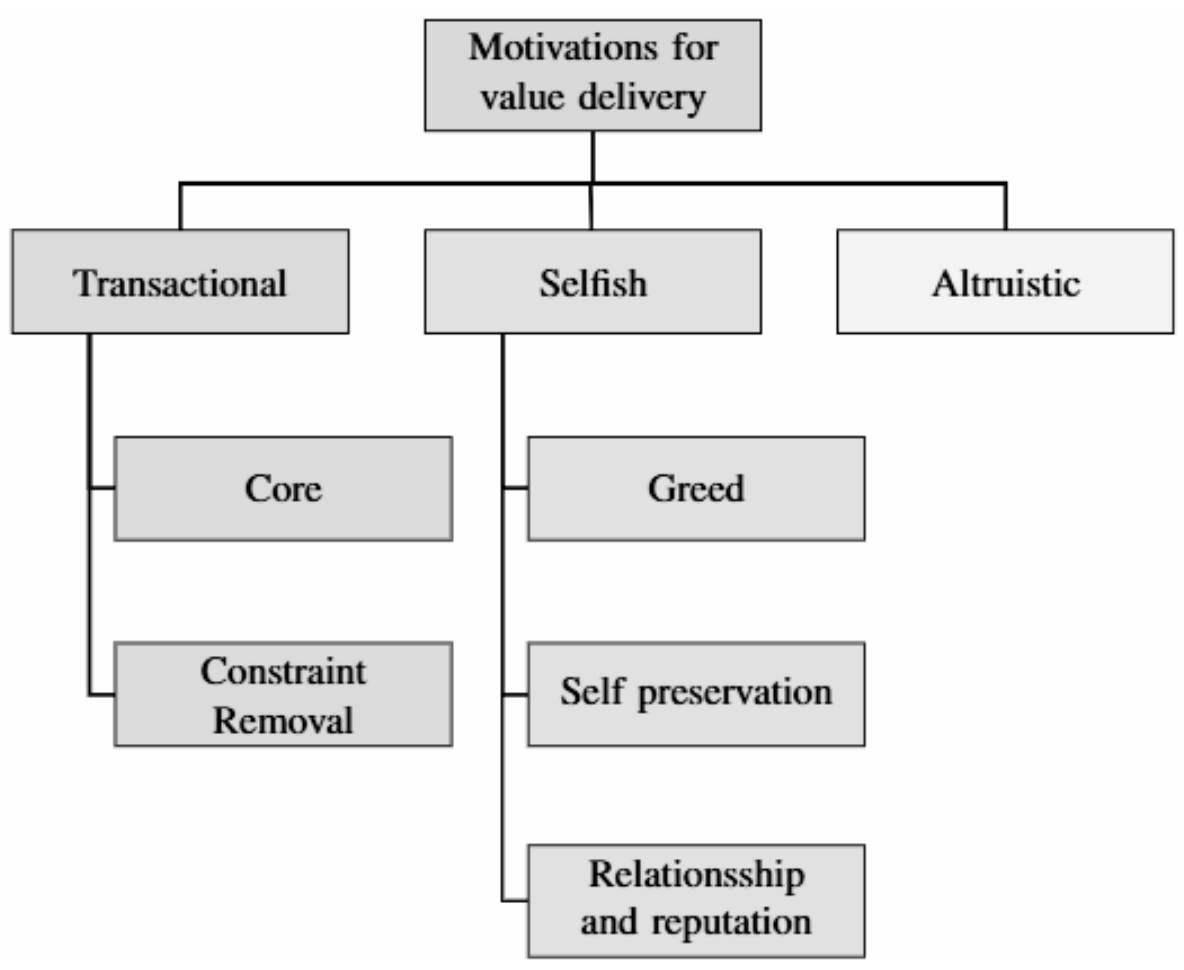

Figure 2: Motivations for value delivery

\section{SELFISH MOTIVATION}

No contract is perfect and all-encompassing, and there are always nuances in regards to deliverables and compensation. Any action taken by a party to the contract to exploit any ambiguities in it, where the intent is to increase value for themselves, can be said to be motivated by greed. Greed is not necessarily bad. However, greed becomes problematic if it leads to an involuntary value reduction for one or more other parties.

Sometimes, actors will deliver value on a project to protect themselves in some way, labelled as self-preservation in Figure 1. For example, Lohne et al. (2017)describe a situation where the contractor in a design-build contract discovered that the fire safety was questionable, and decided on their own accord to upgrade it. The existing solution would pass inspection, and they were not contractually bound to deliver a better solution. However, they choose to do so. While the language of the contract should have exempted the contractor from any future liability from having installed a questionable solution, they did not want to run that risk.

Many designers and builders will have an interest in maintaining a good relationship with the owner for the sake of future business, as well as maintaininga goodreputation in the industry at large. The same holds true for owners vis-à-vis designers and builders. Thus, in many cases, the actors on projects will agree to deliver value to someone else, without being contractually obligated to do so, if this helps their relationship. Alternatively, they might refrain from demanding value, that they rightly would have been entitled to by the contract. 
One of the case projects received noise complaints from the neighbours after doing tests runs of the ventilation system. Even though they did not have any formal obligation to mitigate this, the owner decided to do so to avoiding getting a bad reputation with the neighbours, whom they were dependent on for visits and referrals for their business to be profitable.

\section{ALTRUISTIC MOTIVATION}

In some situations, value will be delivered, not related to the formal transaction nor done for selfish reasons, but rather for altruistic reasons. For example, as part the professional identity, many architects will go above and beyond the minimum requirements laid down by regulations and planning boards related to the urban environment.

\section{OVERLAPPING MOTIVATION}

In the real world, actors will have mixed motivation for delivering some specific value. For example, in the business world, altruistic behaviour would fall under the umbrella of Corporate Social responsibility. Jones et al. (2006)points to several potential benefits of such behaviour: "improved financial performance and profitability; reduced operating costs; long - term sustainability for companies and their employees; increased staff commitment and involvement; enhanced capacity to innovate; good relations with government and communities; better risk and crisis management; enhanced reputation and brand value; and the development of closer links with customers and greater awareness of their needs."

\section{VALUE FOR WHOM - A MATTER OF VALUE PHILOSOPHY}

Returning to the question of whose value matters, those stakeholders that are considered definitive will always matter, as the motivation for delivering value for them is primarily transactional. Definitive stakeholders are all contract partners or have the power to impose on the project through regulatory constraints. However, to what degree they matter is not a clear-cut matter. Going beyond what is part and parcel of the formal contract and the absolute constraints set forth by regulations and governing bodies, will be done based either on a selfish or an altruistic motivation.

Thus, we would argue that the question of value for whom is at its core a philosophical issue. Both as business philosophy, for example, believing that delivering customer value in the short term is better for long-term gains, as well as more generally, for example wanting to contribute in a positive way to society at large. While a conscious and explicit value philosophy might not exist, any entity involved in the construction industry will necessarily have one, albeit maybe unconscious and implied.

A potential issue, then, that should be addressed in projects, is the matter of diverging philosophy's. Especially in the cases where it can be taken from others, motivated by greed, or giving away value not one's own, motivated by altruism. An example of the latter would be an architect providing value for a third party, such as a neighbour, in a way that incurs an increased cost but zero benefits for the owner. The issue then becomes very much one of ethics, further discussion of which can be found in Drevland et al. (2017). 
We would argue, that the notion that whose value matters is a function of the value philosophy of the project participants is significantly different from the underlying notion of previous research on the matter. Although not explicitly stated, our impression of previous papers is that the authors hold to an underlying notion that whose value matters is something that is more or less absolute and constant across projects, and thus can be explicitly defined once and for all.

\section{CONCLUSION}

Having some notion of whose value matters is paramount to being able to optimise projects as production systems aimed at delivering value. The lean construction literature does not provide any clear answer on this subject. Neither does the general literature related to stakeholder management. While the latter can be useful for determining who might want to influence the projects, their ability to do so and their interests, it does little in helping in deciding whose value we should care for, beyond the need to appease those with power

We have argued that the key to deciding whose value matter lies in understanding the motivation for why valueis delivered. However, to what degrees each of the identified factors motivates someone will be highly dependent on their philosophical outlook, thus also making the matter of value for whom a philosophical question. This notion differs significantly from what the views presented by other authors considering this matter.

The main contribution of this paper is that it adds a theoretical discussion that has not been seen in previous studies. Future research will be in the direction of using some of these theoretical models to support teams better understanding how to manage projects with a focus on value generation.

\section{REFERENCES}

Arksey, H., and O'Malley, L. (2005). "Scoping studies: towards a methodological framework." International Journal of Social Research Methodology, 8(1), 19-32.

Bertelsen, S., and Emmitt, S. (2005). "The client as a complex system." 13th Ann. Conf. of the Int'l. Group for Lean Construction, 73-79.

Drevland, F., and Lohne, J. (2015). "Nine Tenets on the Nature of Value." 23rd Annual Conference of the International Group for Lean Construction, Perth, Australia, 475485.

Drevland, F., Lohne, J., and Klakegg, O. J. (2017). "Ethical Dilemmas in Value Delivery: Theoretical Conditions." 25th Annual Conference of the International Group for Lean Construction, Heraklion, Greece, 145-152.

Drevland, F., and Svalestuen, F. (2013). "Towards a framework for understanding and describing the product value delivered from construction projects." 21st Annual Conference of the International Group for Lean Construction 2013, IGLC 2013, The International Group for Lean Construction, Fortaleza, 1004-1014.

Emmitt, S., Sander, D., and Christoffersen, A. K. (2005). "The Value Universe: Defining a Value Based Approach to Lean Construction." 13th Ann. Conf. of the Int'l. Group for Lean Construction, Sydney, Australia. 
Holbrook, M. B. (1998). Consumer Value: A Framework for Analysis and Research. Routledge, London, GBR.

Jones, P., Comfort, D., and Hillier, D. (2006). "Corporate social responsibility and the UK construction industry." Journal of Corporate Real Estate, 8(3), 134-150.

Kelly, J., Male, S., and Graham, D. (2004). Value Management of Construction Projects. Wiley-Blackwell.

Koskela, L., and Ballard, G. (2006). "Should project management be based on theories of economics or production?" Building Research \& Information, 34(2), 154-163.

Laursen, M., and Svejvig, P. (2016). "Taking stock of project value creation: A structured literature review with future directions for research and practice." International Journal of Project Management, 34(4), 736-747.

Lohne, J., Svalestuen, F., Knotten, V., Drevland, F. O., and Lædre, O. (2017). "Ethical behaviour in the design phase of AEC projects." International Journal of Managing Projects in Business, 10(2), 330-345.

Mitchell, R. K., Agle, B. R., and Wood, D. J. (1997). "Toward a Theory of Stakeholder Identification and Salience: Defining the Principle of Who and What Really Counts." The Academy of Management Review, 22(4), 853-886.

Oke, A. E., and Aigbavboa, C. O. (2017). "Construction Projects and Stakeholders." Sustainable Value Management for Construction Projects, Springer, Cham, 49-73.

Pasquire, C., and Salvatierra-Garrido, J. (2011). "Introducing the Concept of First and Last Value to Aid Lean Design: Learning from Social Housing Projects in Chile." Architectural Engineering and Design Management, 7(2), 128-138.

PMI. (2013). A Guide to the Project Management Body of Knowledge: PMBOK(R) Guide. Project Management Institute, Newtown Square, Pennsylvania.

Robson, C. (2002). Real World Research: A Resource for Social Scientists and Practitioner-researchers. John Wiley \& Sons, Oxford, UK; Madden, Mass.

Rorty, R. (1999). Philosophy and Social Hope. Penguin.

Salvatierra-Garrido, J., and Pasquire, C. (2011). "The first and last value model: Sustainability as a first value delivery of lean construction practice." 19th Annual Conference of the International Group for Lean Construction 2011, IGLC 2011, 1-10.

Salvatierra-Garrido, J., Pasquire, C., and Miron, L. (2012). "Exploring value concept through the iglc community: Nineteen years of experience." 20th Ann. Conf. of the Int'l. Group for Lean Construction, San Diego, CA, USA.

Thyssen, M. H., Emmitt, S., Bonke, S., and Kirk-Christoffersen, A. (2010). "Facilitating Client Value Creation in the Conceptual Design Phase of Construction Projects: A Workshop Approach." Architectural Engineering and Design Management, 6(1), 1830 .

Tillmann, P. A., Tzortzopoulos, P., Miron, L. I. G., and Formoso, C. T. (2011). "The Challenges of Managing Stakeholder Requirements in a Urban Regeneration Project." 